\title{
Polymorphism larval stages of Oestrus ovis isolated from frontal sinuses and horn cavities of sheep's head Slay in Basrah abattoir
}

\author{
M. F. AL. Amura \\ Coll.of Vet. Med./ Univ. of Basrah.
}

\begin{abstract}
The study include isolated larvae of Oestrus ovis of diptera from frontal sinuses and horn cavities of sloughted sheep heads. It could be differentiation from another species of Diptera which cause myiasis by some characters. Three stages of the larvae were isolated. In generally the larva stages contain eleven segment, cephalopharngeal skeleton connect with two hooks. The characteristic of L1 stage were white in color, measured L1(3-4mm) in length , have not spines and structure of posterior spiracular have D shape \& yellow in color whereas internally small structure like D shape was present with brown color and the pits or pores occur in whole structure . The L2 stages are slightly grey in color , measurement was (6-12 mm ). In contrast the L3( 20-19 $\mathrm{mm}$ ), with grey to brown in color and have plate dark brown to black color on dorsal surface .posterior spiracular of L2 \& L3 stages have D shape and brown in colors with many spread pores, the ventral surface tegument contain three arrows of spines. Third instar larvae are developed and become pupate during 6-12 hours out of animal body .
\end{abstract}

\section{Introduction}

The myiasis has been define as infestation of live vertebrate animals with dipterous larvae for certain period and feed on dead or living tissue, liquid body substance, or ingested food of the host ( 1) .Larvae of oestrus ovis infestation had taken many terms as synonym, sheep nasal fly, sheep bot fly and oestriosis which belonging to family oestridae, infestation of Oestrus ovis was considers specific myiasis (2) .The life cycle began when female flies deposited their tiny larvae around the nostril (3), the larvae beginning pray on tissue in order to grow than creeping up ward to penetrate the nasal barrier to the frontal sinuses and horn cavities to moult from first stage larvae L1 to second stage larvae L2 and than L3 or ( maggots), these stages cause upset of animals to cause what called false gid (4), thoroughly the sneezing of animal lead to throwing the L3 instar to ground and pupate during 24 hours is developed stays 3-6 week before to hatch to the adult fly (5).Myiasis as generally are dangerous disease on human and animals health. The larvae were caused myiasis which assure harmful to the animals and cause large decay wounds and at spinning season, the larvae move to the frontal sinuses lead loss of growth or may be animal's, body weight loss of $1.1-4.6 \mathrm{~kg}$ of weight and up to $10 \%$ in milk production in infection by Oestru ovis (6).Myiasis were recorded in human,when Chrysomya bezziana occurred in two children (4-8 years ) in Basrah city ( 7 ). Also the infestations of oestrus ovis were recorded in human were record in some countries like Spain when ten person suffer from Oestrus ovis myiasis (8). (9) in kuwait was observed one patient suffered from the symptoms of acute foreign body sensation, irritation, redness, lacrimation and photophobia and reexamined confirm a opthalmomyiasis by Oestrus ovis, also(10) recorder ophalmomyiasis in person at 25 age in India The aim of this study was to isloation and identification of larval stages of Oestrus ovis in slaughtered sheep in Basrah city. 


\section{Material and Methods}

A total of 180 larvae from 42 infected sheep were collected in the sloughters houses in basrah city during the period from ( April , May- 2010).The samples of different stages of larvae from frontal spaces and horn cavities of sheep after sloughterin abattoir were taken, then the larvae were kept in ethyl alcohol $70 \%$ and others in formaline $10 \%$ then sent to the laboratory for diagnosis.A procedure by (11) was done depended upon the samples which prepared in laboratory in order to recognize the diagnostic features which included the posterior end spiracles and cephalopharngael skeleton, as the following:

\section{Results}

The infected sheep by Oestrus ovis in many barns had suffer cliniclly from nasal discharge and in sever cases combination with bleeding, sneezing and at sometime expelled out, head shaking, fever, pneumonia.In the abattior the postmortum showed different larvae which are settle in frontal sinuses of the head horns' cavities, also observed inflammation fluid \& congested area figure (1-2).Larval stages: The general structure of larvae consist of eleven segment or rings, Differents posterior spiracular ( Figure 3 ), three arrow of spines in ventral surface of rings, and cephalopharngeal skeleton connect with two hooks. Also showed different stages of larvae with different measurement ( figure 4).

1- First stages larvae (L1): white in color, the measurement was 3-4 $\mathrm{mm}$ in length, posterior spiracular were smal and like D shape the whole structure have spread pores
1- cut the target part and washed with normal saline and then these parts were kept in solution of sodium hydroxid $10 \%$ for 24 hours .

2- washed these parts with normal saline for 10 minutes, repeated wash for three times

3- The samples were passed an ascending concentration of ethanol $35 \%, 50 \%, 70 \%$, $90 \%, 100 \%$.

4-Samples were kept in mixed solutrion of xylol and ethanol (1:1) for 10 minutes.

5- samples were passed in abslute xylol for 5-10 minutes.

6- The samples were mounted on slids and fixed by canada blism and left 24 hours on hot plate and inspect under microscpe .

or pits which are separated by fine tubercles , and loss of spines, (figure 5,6).

2- Second stage larvae(L2): slightly grey in colour, the measurment was 6-12 $\mathrm{mm}$ in length, have clearly three arrows of minutes spines, the posterior spiraculars brown in colour and have D shape the pores separated by fine tubercles ( figure 7,8,9).

3- Third stage larvae (L3): brown to grey in colour, the measurment $19-20 \mathrm{~mm}$ in length three lines of large clearly spines, dark brown plates in dorsal surface of larvae, the posterior spiracular brown in colour with $\mathrm{D}$ in shape and the pores separated by fine tubercles ( figure $10,11,12$ ).

-Third stage larvae were transsformed to pupate during 12-24 hours ( the tugument began to shrinkag and soliditation, ( figure 13 and 14 ).

-Cephalopharngeal skeleton connect with two hooks like sickle present in anterior end, tugument with three arrow of spines (figure 15,16, 17,18). 

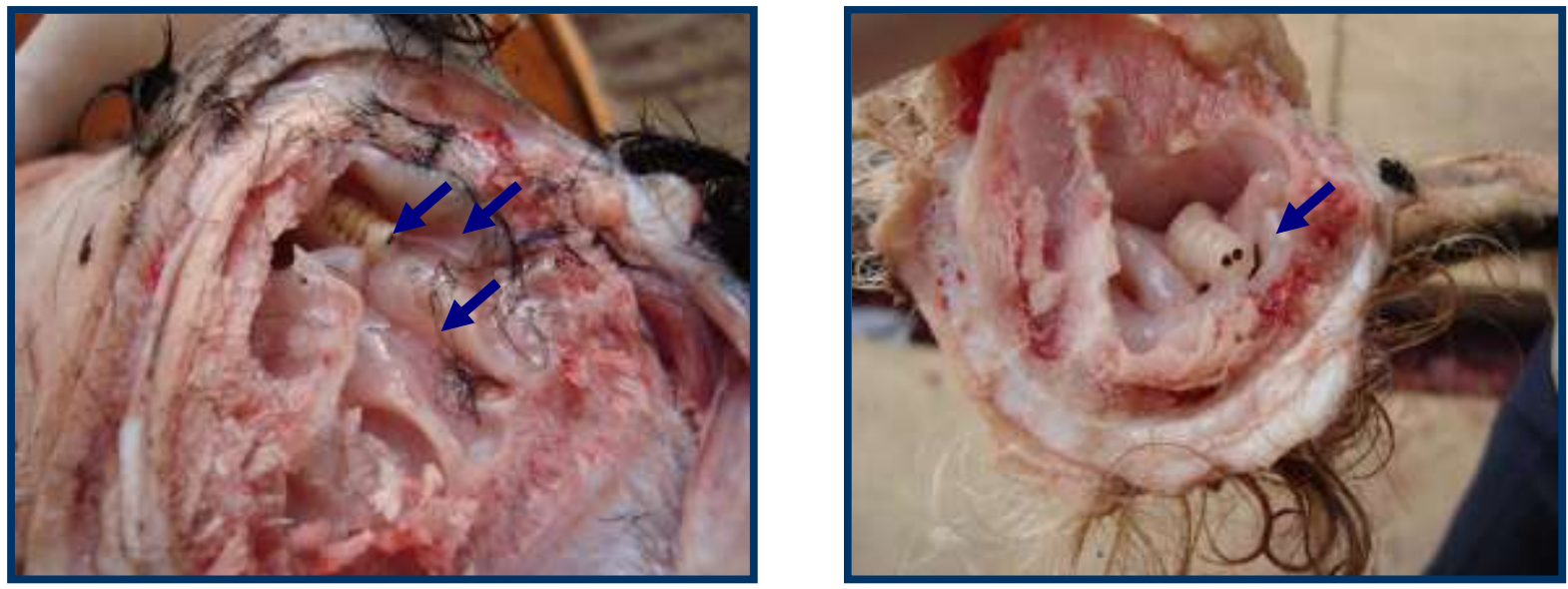

Figure (1, 2 ): Larva in front-sinuses and horn cavities ( $~$ ), inflammtion fluid in infection sites ( $)$

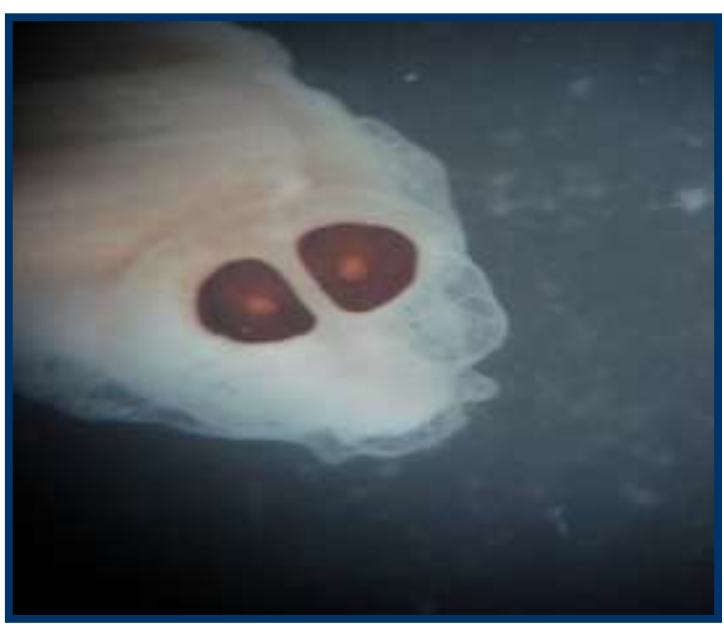

Figure (3): Posterior spiracles before prepare to slides



Figure (5) : first stage larvae (L1) $(4 \mathrm{~mm})$



Figure (4): different stage larvae

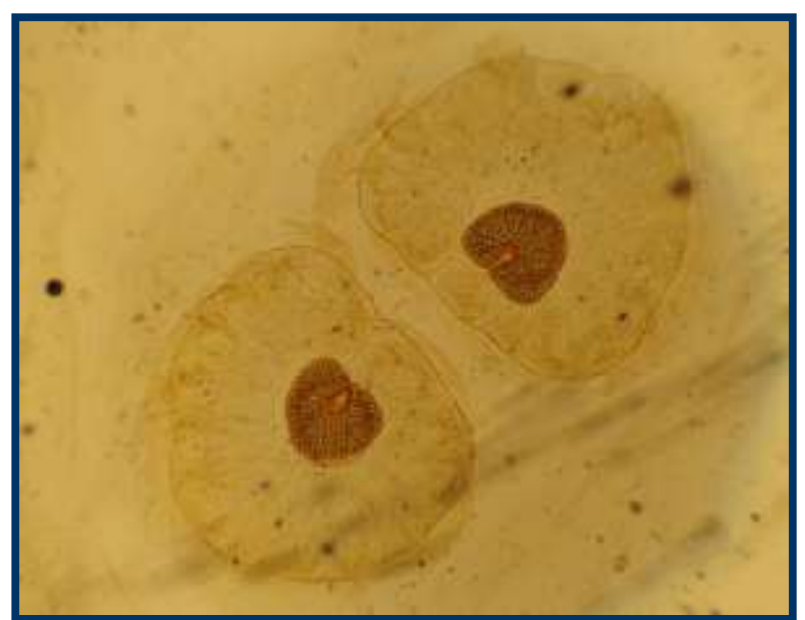

Figure (6) Small Posterior spiracular of L1 


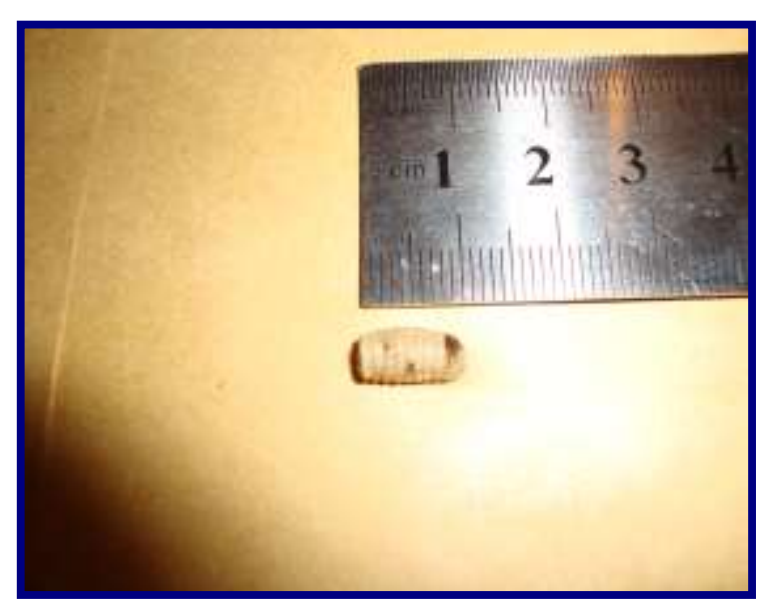

Figure (7) : second stage larvae (L1) $(9 \mathrm{~mm})$

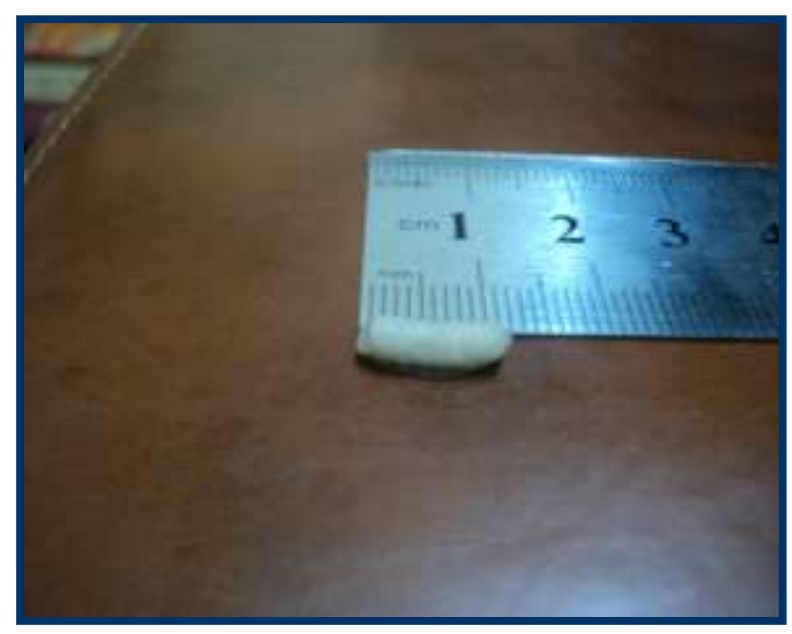

Figure (9) : second stage larvae (L2) (12mm)

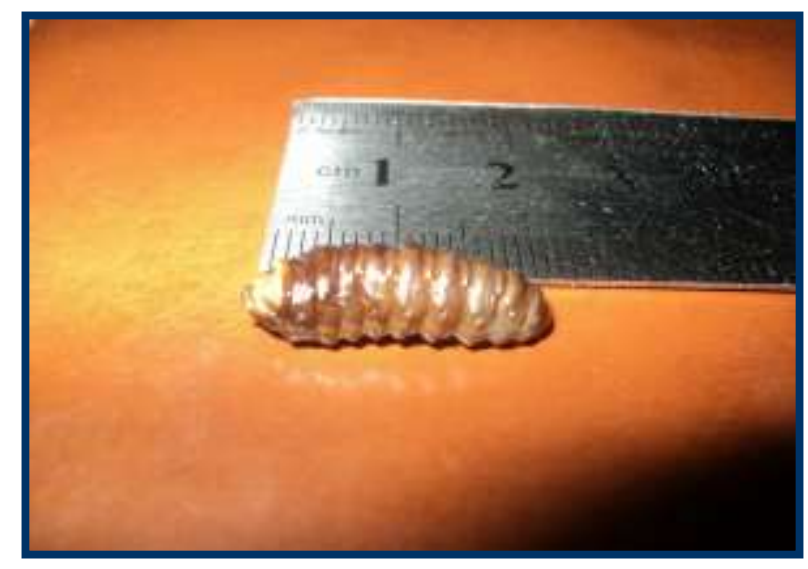

Figure (11) : Third stage larvae (20mm)



Figure (8): ( A) tubercules, B) pores , (C)extended active spiracular

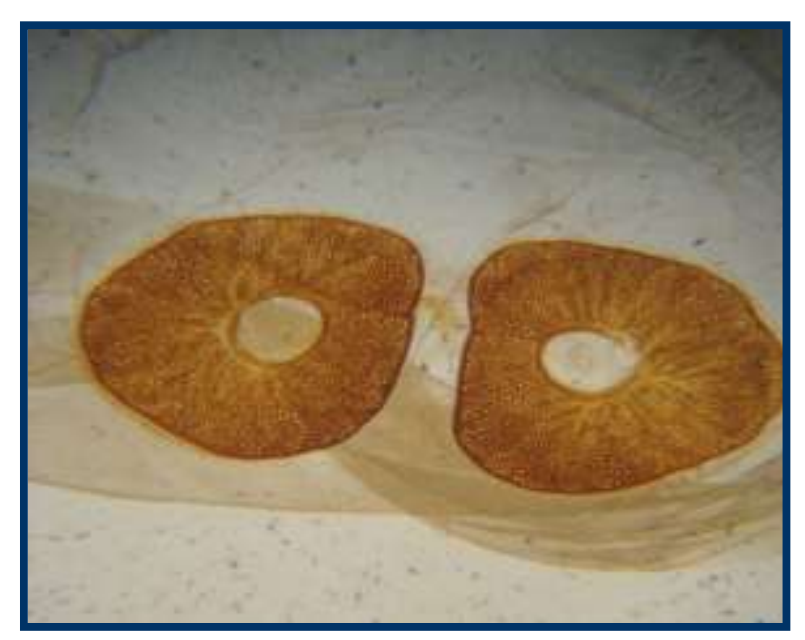

Figure (10) : complete extended posterior spiracular especially in L3

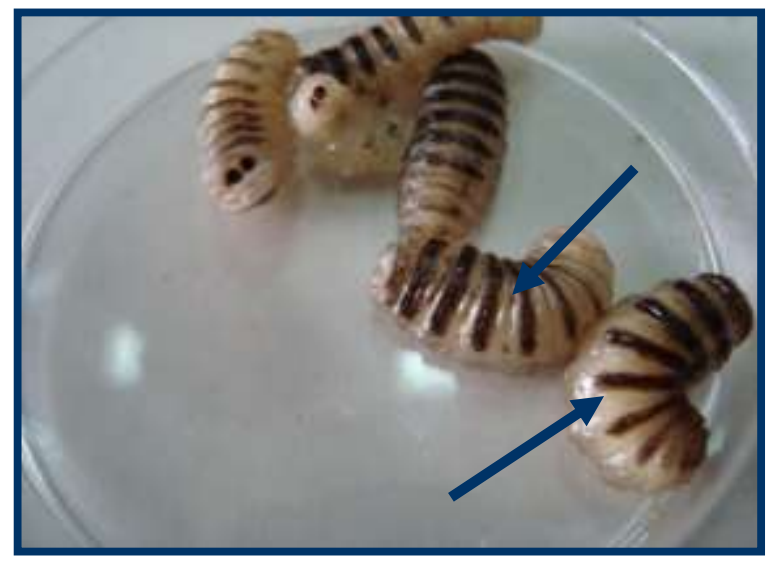

Figure (12) : third stage larvae (9mm) With spiracular plate dorsally 


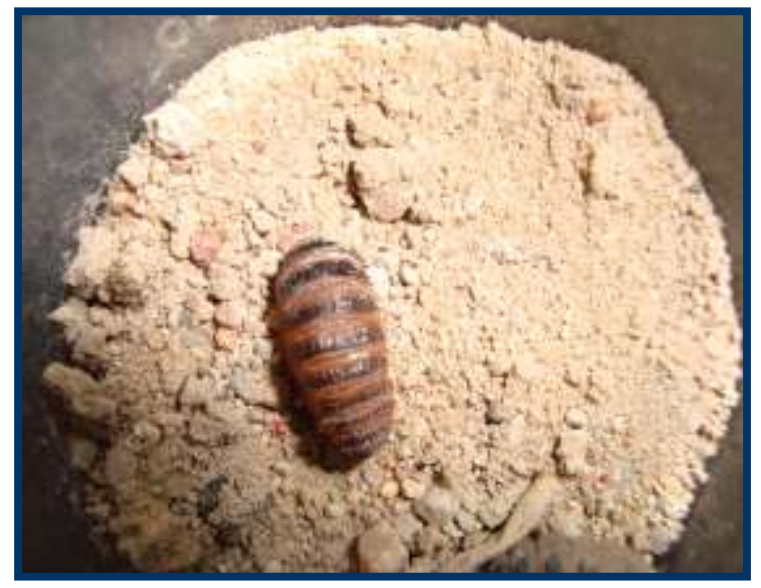

Figure (13) : Third stage larvae began transform to pupate during 12-24 hours ( the tugument began to shrinkag )

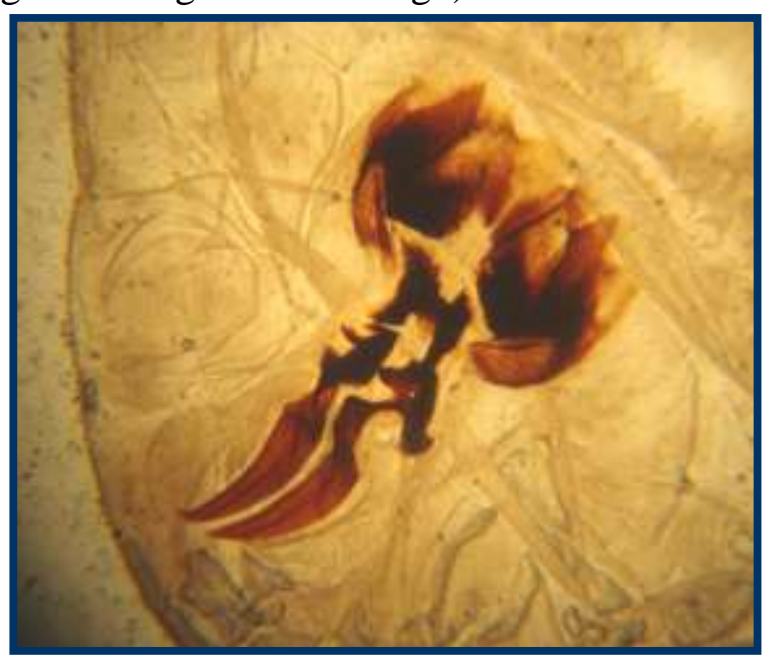

Figure (15) : Cephalopharngeal skeleton in larvae of Oestrus ovis

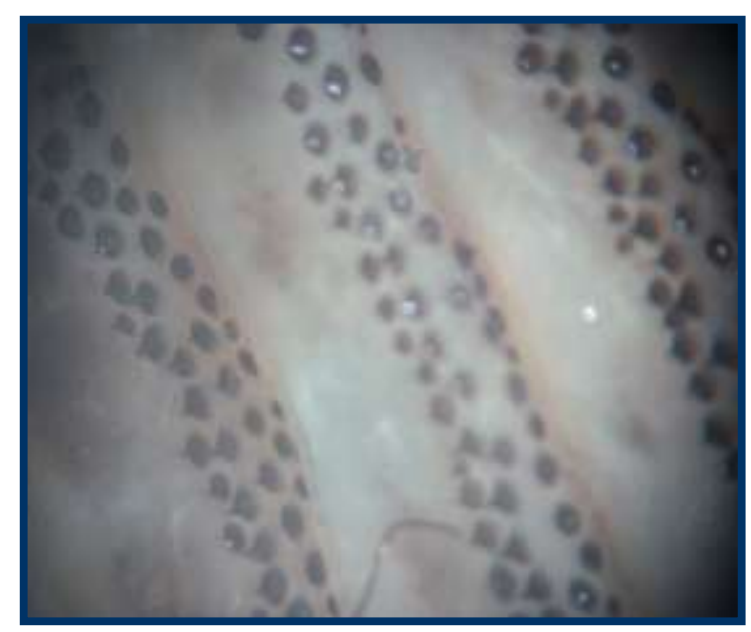

Figure (17): show three arrow of spines in tegument of L2,L3 stages of Oestrus ovis

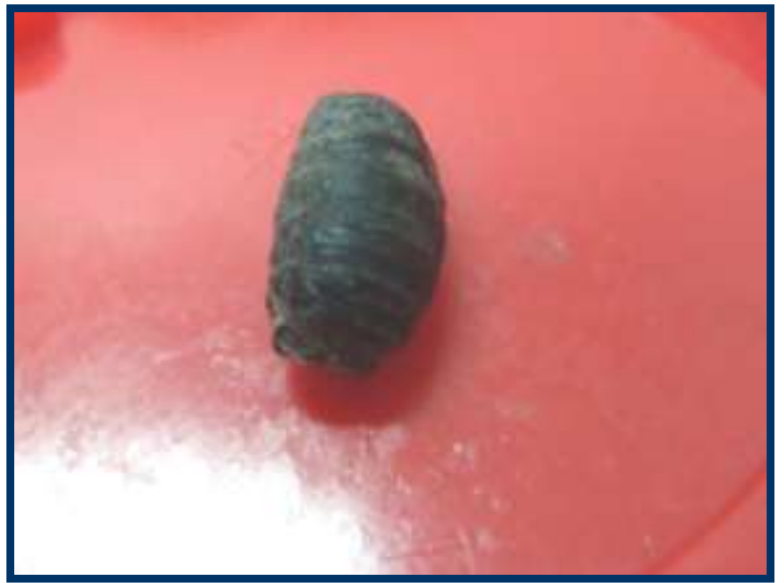

Figure (14) : pupate after 24 hours

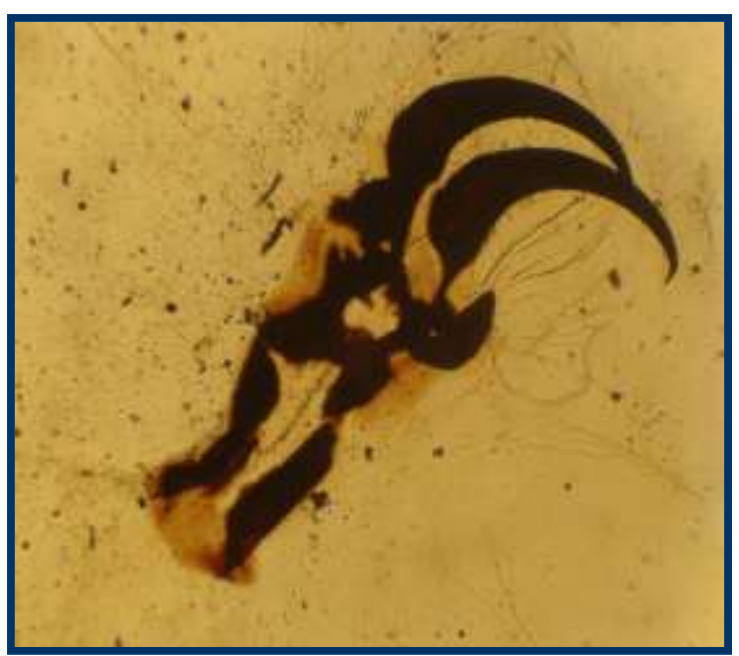

Figure (16) : Cephalopharngeal skeleton in larvae of Oestrus ovis

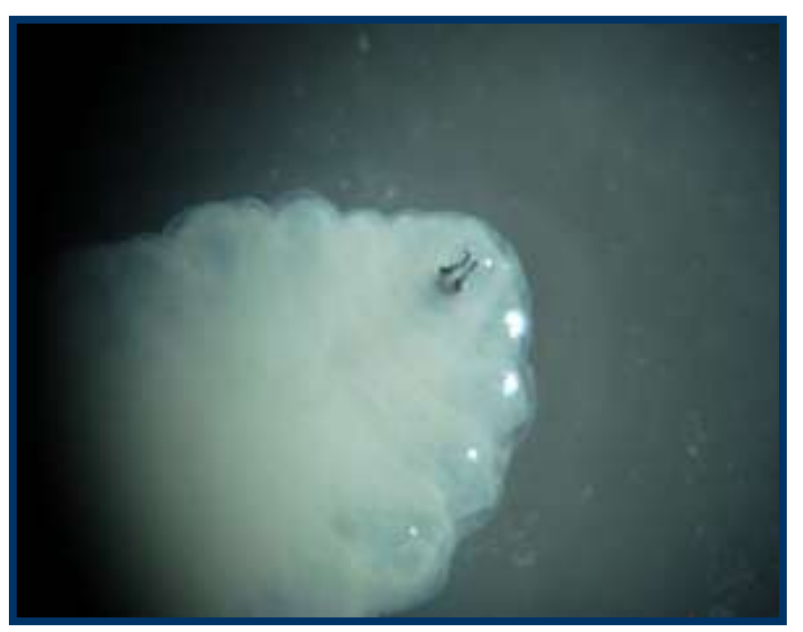

Figure (18): L1 stage loss spines in tegument 


\section{Discussion}

The Oestrus ovis is very important flies of Dipetra that cause myiasis in head cavities of sheep and rarely in goat. It is also have a risk in human health with wide spread or become outbreak (12) . (13) was identified the dipetra depend on infection site such as Hypoderma bovis which parasitized the cattle skin and Oestrus ovis in nostile, while the accurate diagnosis involve the isolation of larvae from deepest part of infection sites inorder to examination of different stages of the larvae (14).The infectious animals were suffered from nasal discharge with staining by blood, also internally the inflammation fluid were found around larvae in sinuses that confirm the response of immunity system against the larvae, nevertheless ( 15) refer to hypersensitive reaction at the site of tissue invasion with a massive infiltration of eosinophils and mast cells in the nasal mucosa beneath the epithelium.The collection 4-16 Oestrus ovis larvae from frontal space and horns cavities of one to two infected animals confirm the intensity of infection, this may be due to the present of predisposing factors to spread of Oestrus ovis like temperature, wind and solar irradiance (16).(1) and (17) were identified a key to classification the larvae belong to dipetera, its precious characters of Oestrus ovis than others larvae of dipetera are present numbers of segment, number of lines spines and especialy the form and structure of posterior spiracles.In generally the maggots of oestrus ovis have eleven ring also considers one diagnositic feature( 18) remained the Oestrus ovis have 12 segment but the one and two segment are connected .whetever it contrast with other species such as Musca domestica.The larvae of diptera have different characters in posterior spiracles in shape or structure, Larvae of Oestrus ovis have spiracles D shape whereas in Chrysoma bezziana the as plates and in Lucilia sericata as pyiform (19).A new record to describe L1 which have posterior spiracular as form like D shape with yellow colour whole size but centrally is brown colour and pits well show extended in all structure of spiracles. In L2, L3 the posterior spiracles are also $\mathrm{D}$ shape and brown colour with pits that agree with (20) was refer to found many of pits in spiracles of Oestrus ovis when classified the third instar larvae.The $\mathrm{L} 1$ length was $3 \mathrm{~mm}$ in measurement and this was result agree with (21) who refere to L1 length was $1-3 \mathrm{~mm}$ and loss of spines in larvae tugumment, After grown of L1 average larval length increased therfore transform to L2 (length 6-12 $\mathrm{mm}$ ) and than to L3 (length 19-20 $\mathrm{mm}$ ), however the (22) in study of Weight of Oestrus ovis showed that the weight of L1, $\mathrm{L} 2, \mathrm{~L} 3$ the weight increased from $0.23 \mathrm{mg}$ in $\mathrm{L}_{1}$ larvae to $49 \mathrm{mg}$ in late $\mathrm{L}_{2}$ larvae and $\mathrm{L} 3$ aquired weight 518.The spines of Oestrus ovis were minutes in L2 and clearly in L3 stages whoever (23) was described the spines of Chrysoma albiceps and Chysoma rulifacies like hairy and smoth, Also the L1 loss spines whereas the L2, L3 have three arrows of spines in ventral surface of tugument that agree with (24) which was remind especially the L2, L3 Oestrus ovis as arranged the spines in three lines. The hooks were connected internally to cephalopharngeal skeleton in oestrus ovis so (25) refer the Cochliomyia hominivorax and Chrysomya bezziana have same structure of cephalo-pharngeal skeleton and all genus of Diptera.Larvae need protein to be growth and reach to instar L3; however, began transform to papuat ( papuation process: its soliditary of tegument to began new stage is generation fly) (26) use genetic analysis for isolation DNA ( L1, L2, L3) of Oestrus ovis (27 ) using crude protein from second stage larvae as antigen for seroprevalence by ELISA. 


\section{References}

1. Zumpt, F. (1965). Myiasis in man and animals in the Old World. London, Butterworths. pp267.

2. Faust, E. C.; Beaver, P. C. \& Jung, R. C. (1974). Animal agents \& vectors of Human Disease. 4 th. Edit. Henry Kempton publishers London. Philadelphia. 237-243

3. Roberts, L. S. \& Janovey, J. J. (2005). Foundation of Parasitology. $5^{\text {th }}$ ed. Wm. C. Brown Publisher. The McGraw Hill Companies. Inc. Pp: 659.

4. Blood, D. C. and Henderson, J .A. (1973). Veterinary Medicine Fourth edition. Baltimore, The Williams and Wilking company Pp963.

5. Aitken, I. D. (2007). Disease of sheep , fourth ed. Turbridge wells. UK. PP: 335-336.

6. Ilchmann, G.; Betke, P.; Grafe, D. and Gossing, S. (1986). Untersuchungen zur oestrose und ihre bekampfung in der Mongolischen Volksrepublik Monatshefte fur Veterinarmedizin 41: 128-132.

7. Al-Rubia, K. K.( 1998). Human cutaneous myiasis report of cases associated with head lice caused by Chrysoma bezziana ( Diptera :calliphoridae ). Basrah J . Scie. 16 ( 2): 23-26.

8. Quesada, P.; Navarrate, M. L. and Measo, J. (1989). Nasal myiasis due to Oestrus ovis Larvae Ear arch otochinolaryngol .Department of otochinolaryngol . Autonomous university, Barcelona , Spain 247:131-132.

9. Hira, P. R.; Hajj, B.; AL- Ali, F. and Hall, M. J. (1993). Opthalmomyiasis in Kuwait: First report of infection due to the larvae of Oestrus ovis before and after gulf conflict . Department of Microbiology, Faculty of Medicine, Kuwait University J. Trop. Med. Hyg., 96 (4): 241-4.
10. Pandey, A.; Madan, M.; Ashana, A. K.; Das, A.; Kumar, S. and Jain, K. ( 2009). External Ophthalmomyiasis Caused by Oestrus ovis: A Rare Case Report from India . Korean J. Parasitol., 47 (1): 57-59.

11. Spradbery, J. P. (1991). A Manual for the Diagnosis of Screw-worm Fly. Commonwealth Scientific and Industrial Research Organization (CSIRO) Division of Entomology, Canberra, Australia, 64 pp.

12. Scala , A.; Solinas, G.; Citterio ,C.V.; Kramer ,L .H.and Genchi,C.(2001) .Sheep oestrosis ( oestrus ovis Linne 1761, Diptera :Oestridae) in sardinia italy .vete. parasitology, 102 :133141.

13. Abo-alhab , J.K .(1978) . medicine insects in Iraq . College of Agriculture . University of Baghdad. Pp227.

14. Alcaide, M.; Reina, D.; Sanchez,J .; Frontera, E. and Navarrete, I. (2001). Seasonal variation in the burden distribution of Oestrus ovis in sheep in southwest of spain, Vete . parasitology , $118: 235-241$.

15. Otranto ,D. (2001) . Immunology of myiasis : parasite survivaland host defense strategies .Trends in parasitology . p p 176-182.

16. Cepeda-Palaios, R. and Scholl, P. J. ( 2000). Factor effecting the larvae positional activity of Oestrus ovis gravid females ( Diptera : Oestridae ). Vete. Parasitol., 91: 93-105.

17. James, M. T. (1947). The flies that cause myiasis in man. USDA Misc. Pub. 631:175.

18. Soulsby, E. J. L. ( 1986). Helminth , Arthropods \& Protozoa of Domesticated animals . 7 th Edition, Baillier ,Tindall.

19. Al- Helfie , M.M \& Nadham ,K.M.(1999) Case of myiasis in skin of goat by larvae of Lucilia sericata .Basrah J.Sci , 80-79 
20. Al- Helfie, M .M. (2001) . Taxonomical and Ecological study on the medical insects ( order Diptera ), caused myiasis, in Basra province with a mention to its control. MSc thesis .Iraq . College of Science . university of Basra. Pp105 .

21. Hendrix, C. M. and Robinson, E. D. (2006). Diagnostic Parasitology for veterinary technicians .Third edition. Health science department. Philadelphia. PA.USA.Pp285

22. Cepeda-Palacios, R.; Avila, A. and Ramirez-Orduna, R. (1999) .Estimation of the growth patterns of Oestrus ovis larvae hosted by goat in baja California sur mexico. Vete. Parasitol. 86: 119-126.

23. Hall, M. J. R. (1990). Screwworm flies as agents of wound myiasis .food and agriculture organization of the united nations .

24. Soulsby, E. J. L. ( 1968). Helminth , Arthropods \& Protozoa of Domesticated animals .6 th ed.pub.Bailiere tendall . London . Pp 141.

25. Smith, K.G.V. (1986). A manual of forensic entomology. London, British Museum (Natural History). 205 pp.

26. Grisez- Duranton, C. (2002). Genetic structure of Oestrus ovis populations in sheep and goats Vete. Parasitol. 104: 167-173.

27. Alcaide, M.; Reina, D.; Frontera, E. and Navarrete, I. (2005). Epidemiology of Oestrus ovis ( linneo ,1761) infestation. Vete. Parasitology,130: 277-284.

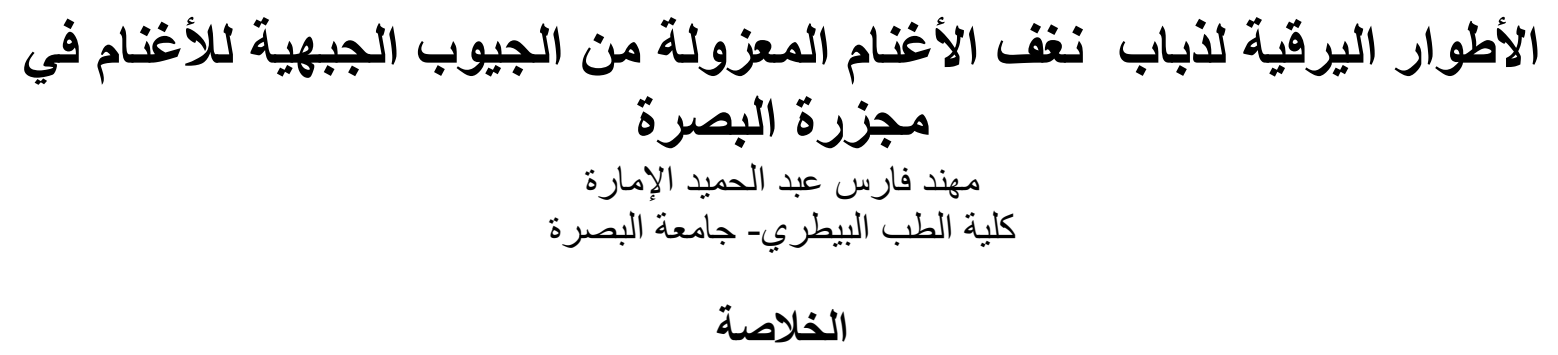

تضمنت الدراسة عزل ئن Oestrus ovis من الجيوب الجبهية و التجاويف القرنية لرؤوس الأغنام المسلوخة , من المككن

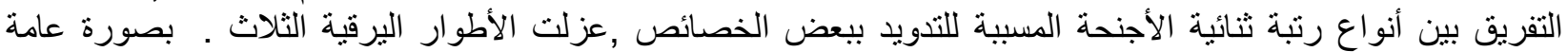

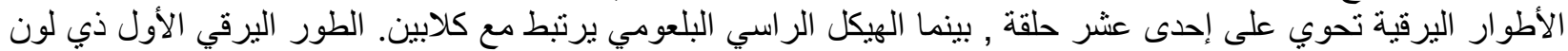

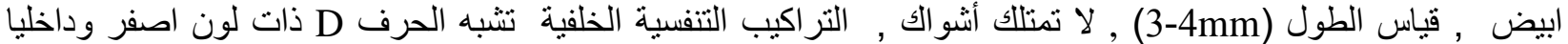
تمتلك تركيب تنفسي صغير يشبه الحرف D ذي لوني لون بني بينما الثغرات التنفسية موجودة في التركيب الكلي. الطور اليرقي

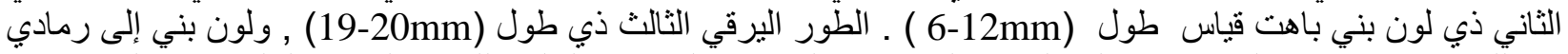

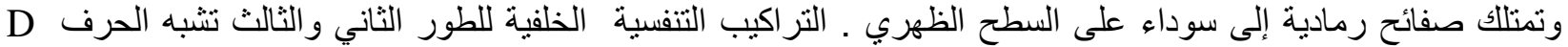



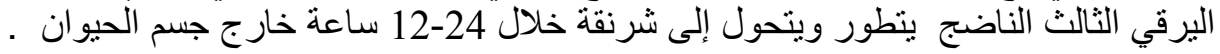

